\title{
Sipos GÁBor*
}

\section{SZÁZADI SVÁJCI NYOMTATVÁNYOK A KOLOZSVÁRI FÖISKOLAI KÖNYVTÁRAKBAN"*}

\author{
Kulcsszavak: kora újkori Erdély, Kolozsvár, régi nyomtatványok, Svájc, kollégiumok
}

A 16. századi svájci kiadványok kora újkori erdélyi recepciójához szeretnék adalékokkal szolgálni az alábbiakban, ahogyan az a három kolozsvári egyházi kollégium könyvtárának mai állapotában tükröződik. Közismert a svájci államszövetség (amelyhez 1501-ben Bázel is csatlakozott) nyomdász-kiadóinak meghatározó szerepe az európai tudományos művek megjelentetésében, ${ }^{1}$ az általuk közreadott kötetek erdélyi elterjedése ezért a hazai olvasmánytörténet fontos részét képezi. Három kolozsvári főiskola könyvanyagának ilyen szempontú vizsgálata nyilván nem derítheti fel a használat, a befogadás minden részletét, ráadásul a gyüjtemények teljes 16. századi helvetica-anyagának bemutatása szétfeszítené az adott kereteket, de bizonyos tendenciákra még e részleges közlés is rávilágíthat, és részben pótolhatja a szóban forgó könyvtárak mindeddig hiányzó antikvakatalógusát.

Erdély „civitas primaria”-jában katolikus, református és unitárius kollégium működött a 16-17. században, elöljáróban a könyvtáruk rövid történetét vázolom, mégpedig a létrejöttük sorrendjében.

Az unitárius kollégium a helybéli plébániai iskolának a jogutódja, amely a város felekezeti változásaival párhuzamosan 1569-től fogva vált antitrinitárius jellegűvé. Az óvári volt domonkos kolostor épületében múködő főiskola könyvtára valószínúleg megörökölte az ott található középkori könyvanyagot. Mivel az antitrinitárius oktatás a katolikus könyvörökségnek kevés hasznát vehette, folyamatosan gyüjthették a friss teológiai és polemikus irodalom hazai és külföldi termékeit. A könyvtár osztozott a kolozsvári unitáriusok viszontagságos sorsában, 1603 októberében Giorgio Basta császári generális a nagypiaci (fótéri) templomot és az óvári iskolát a katolikusok kezére adta, és ez alkalommal az eretneknek tekintett könyveket elégettette. A 17. században a tűzvészek pusztításaitól eltekintve gyarapodott a könyvtár, főként adományokból. Az unitárius egyházközség könyvtárát is beolvasztották, így ez a kolozsvári könyvtár lett az erdélyi unitáriusok reprezentatív könyvgyüjteménye. ${ }^{2}$

A római katolikus főiskolát Báthory István alapította, 1579-ben hívta be a jezsuitákat Erdélybe, akik 1581-ben kolozsvári rendházuk mellett kollégiumot hoztak létre. Báthory egye-

\footnotetext{
* Sipos Gábor (sz. 1951), művelődéstörténész, az Erdélyi Református Egyházkerületi Levéltár munkatársa, egyetemi docens, az EME elnöke.

** A 2013 áprilisában Zürichben Humanistischer Wissenstransfer zwischen der Schweiz und Ostmitteleuropa címmel tartott konferencián elhangzott előadás jegyzetelt és kibővített magyar változata.

1 Fritz Funke: Könyvismeret. Osiris, Bp., 2004. 151, 168.

2 Bíró Gyöngyi: Az unitárius egyházi értelmiség könyvtárai a XVI-XVII. századi Kolozsvárott. Magyar Könyvszemle 116(2000). 2. sz. 131-139. (a továbbiakban Bíró 2000.)
} 
temmé szándékozott fejleszteni a főiskolát, ez azonban nem valósult meg, mivel a jezsuitákat sok viszontagság érte a túlnyomóan protestáns országban. A Jézus Társaság atyái rendi fóiskolájuk számára kezdettől fogva a legkorszerübb szakirodalmat gyüjtötték, nem feledkeztek meg azonban a protestáns Erdélyben gazdátlanná vált katolikus könyvörökség megőrzéséről sem. A jezsuita főiskola első könyvtárának anyagát Jakó Klára rekonstruálta, a föltárt szinte 500 kötet között több könyvgyưjtő hagyatéka is szerepel. ${ }^{3}$ Amikor 1607-ben a jezsuitákat végleg kitiltották Erdélyből, értékes könyvgyüjteményük nem került ki az országból, hanem Kolozsvárott titokban letétbe helyezték. Az erdélyi kormányzat a 17. században hallgatólagosan elnézte a jezsuiták jelenlétét, sőt azt is, hogy Kolozsmonostoron iskolát tartsanak fenn a katolikus papi utánpótlás biztosítására. Ide kerültek át később a letétbe helyezett könyvek is. A rendház 17. századi újabb beszerzései részben vásárlásból, részben adományokból származtak. A Jézus társasági atyák láthatólag tudatosan gyüjtötték a protestáns teológiai irodalmat is, a címlapra eligazításul rá is vezették, hogy „Protestans”, vagy „Liber haereticus”. A rendház és a kollégium 1693-ban költözött be Kolozsvárra, a 18. század elején a könyvtár állománya kb. 1500 kötetre tehetô. ${ }^{4}$

Kolozsvárott a 17. század első évtizedében szerveződött újjá a református egyházközség, a kálvinisták már kezdetben iskolát létesítettek és gondoskodtak a tanításhoz szükséges minimális könyvanyag beszerzéséről. Középkori könyvörökség hiányában az iskolai könyvgyüjtemény csak a tanintézetet magáénak tartó kálvinista társadalom, elsősorban az utánpótlásért felelősséget érző értelmiségiek könyvadományaival gyarapodhatott. A legkorábbi ismert adományozó az 1624 januárjában elhunyt Csepei Sidó Ferenc kolozsvári lelkész, 20 kötetnyi ismert hagyatékában latin nyelvü, elsősorban teológiai témájú külföldi kiadványok találhatók. Lelkészek és tanárok adományaival a 17. század végére a könyvtár állománya kb. 1000-1100 kötetre gyarapodott. ${ }^{5}$

Mivel a kora újkori erdélyi könyvpiac távol esett a nyugat-európai központoktól, a főiskolai könyvtárak állománygyarapítása ritkán valósult meg friss beszerzésekkel, inkább az adományokra alapozódott. Összetételük ezért a korabeli erdélyi társadalom felekezetek szerint eltérő könyvgyüjtési és könyvhasználati szokásait tükrözi. ${ }^{6}$ Ilyen körülmények között is jelentős számban került 16. századi svájci kiadású mű a főiskolák könyvtáraiba, közleményem ezért szükségképpen válogatás, amely igyekszik tükrözni az iskolai gyüjtemények jellegzetességeit.

A három főiskola elsősorban a lelkészutánpótlást szolgálta, könyvtáruk svájci kiadású könyvei között a teológiai anyag dominál. Először a bibliakiadásokat véve szemügyre megállapíthatjuk, hogy a Nicolaus de Lyra glosszáival megjelent ívrétű kiadás (Bázel 1506) több kötetét is beszerezte a kolozsvári jezsuita kollégium még 1604 előtt. A Mózes öt könyvét tartalmazó, fametszetekkel díszített első kötet kissé rongált állapotú fatáblás barna bőrkötésben

3 JaKó Klára: Az elsö kolozsvári egyetemi könyvtár története és állományának rekonstrukciója 1579-1604. (Adattár XVI-XVIII: századi szellemi mozgalmaink történetéhez 16/1). Scriptum, Szeged, 1991. 9-31. (a továbbiakban JAкó 1991.)

4 György Lajos: A kolozsvári római katolikus Lyceum-könyvtár története. Bp., 1994. 15-24., 31-55. (a továbbiakban György 1994.)

5 Sipos Gábor: A kolozsvári Református Kollégium könyvtára a XVII. században. Scriptum, Szeged, 1991. 11-12. (a továbbiakban Sipos 1991.)

6 MonoK István: Az olvasott örökség - hagyomány és megújulás. = Kulturális örökség - társadalmi képzelet. Szerk. György Péter, Kiss Barbara, Monok István. OSZK-Akadémiai, Bp., 2005. 84-85. 
maradt fenn. ${ }^{7}$ A negyedik és a hatodik rész egy kötetben áll ma is a könyvtár polcán. ${ }^{8}$ Egy görög-latin bibliakiadás harmadik része (Bázel 1550) egykorú erdélyi kötésben került a jezsuita könyvtárba. ${ }^{9}$ Nem hiányzott az Újtestamentum görög-latin kiadása (Zürich 1559), sem, ezt a példányt 1595-ben vásárolta uzoni Béldi Pál, a jezsuiták pedig 1604-ben katalogizálták. ${ }^{10}$ A Junius, Tremellius és Beza nevével fémjelzett svájci kiadások hat példánya található ma a katolikus Lyceum-könyvtárban, az Erasmus nevéhez köthető latin újtestamentumból pedig két példányt (Bázel 1522, Zürich 1550) őriznek ugyanitt. ${ }^{11}$ Érdekességként említem, hogy egy német-svájci fordítású Újtestamentum is szerepel a gyújteményben, ez korábban a gyulafehérvári trinitáriusok tulajdonában volt. ${ }^{12} \mathrm{~A}$ református kollégium könyvtárát gyarapító adományozók is használtak svájci kiadású bibliákat: az Erasmus fordította Újszövetséget (Novum Testamentum ...ex versione Erasmi. Glossa... M Flacii Illyrici. Bázel 1570) az 1689-ben elhunyt Szentiványi Márkos Dániel unitárius püspöktől szerezte be Kabos Pál, aki 1699-ben a kollégiumnak adta, ${ }^{13}$ a Vatablus-féle ívrétú Biblia poliglotta (Genf 1587) pedig a 18. század elején került a kollégium tulajdonába. ${ }^{14}$ Munkácsi András 1696 táján lépett be a tógátus diákok sorába, 1699-ben pedig egy bázeli kiadású görög Újtestamentumot adományozott fölnevelő iskolájának. ${ }^{15}$ Sebastian Münster rendezte sajtó alá Máté evangéliumának héber nyelvű kiadását, a Bázelben kinyomtatott munka 1622-ben magyar tulajdonban volt, az 1670-es években jutott a református főiskola tulajdonába, 1692-ben az újraköttetéséről kellett gondoskodni. ${ }^{16}$ Magától értetődő, hogy a Sebastian Castellio által kiadott ívrétű Szentírás (Bázel 1556) megvolt az unitárius egyházközség könyvtárában korábbi tulajdonosa, id. Frank Ádám lelkipásztor jóvoltából. ${ }^{17}$ Az unitárius kollégium az 1573-as bázeli kiadást is megszerezte, ez egyébként a katolikus könyvtárba is bekerült. ${ }^{18} 1697-b e n$ kapta ajándékba ifj. Szőrös János özvegyétől a kollégium diákközössége azt a Robert Etienne által közreadott folio méretű bibliát, amelyet korábban Everard Spangenberg és Valentin Radecius kolozsvári unitárius lelkipásztorok forgattak. ${ }^{19} \mathrm{Az}$ Újszövetség görög-latin vagy latin, Beza vagy Erasmus

7 Textus Biblie cum glosa. Basileae 1506, Frobenius. A Román Akadémia Kolozsvári Fiókja Könyvtára (a továbbiakban AkKvt) C 90944.

8 Quarta pars Biblie cum exp. Lyre. Basileae 1507, Sexta pars Biblie Lyre. Basileae 1508, Frobenius. AkKvt C 102446.

9 Bibliorum Graec. Lat. pars tertia. Basileae 1550, Brilyngerus. JAkó 1991. nr. 76.

10 Tes kaines diathekes apanta, Novum Iesu Christi testamentum. AkKvt C 50651, Jakó 1991. nr. 308.

11 AkKvt C 58264, C 57228.

12 Das Alt Testament dütsch. Zürich 1525, Froschover. „Residentiae Carolin. PP Trinitariorum” AkKvt C 59572.

13 „Danielis Szent Ivani”, „Ex oblatione gratuita Generosi D[omi]ni Pauli Kabos obtinet Collegium Claud[iopolitanum] Ref[ormatum] Anno 169928 martii.” AkKvt R 82240, Sipos 1991. 53.

14 AkKvt R 82395.

15 Novum Testamentum graecum. Basileae 1538, Sipos 1991. 78.

16 Sebastianus Munsterus: Evangelium secundum Matthaeum in lingrva hebraica. Basileae s. a. AkKvt R 82351. Sipos 1991. 81.

17 „Ex libris Adami Franci sit.” Ecclae Unitar. Claud.” AkKvt U 74408.

18 AkKvt U 75455, C 51469.

19 Biblia utriusque Testamenti... [Genevae] 1556/1557. AkKvt U 60288. „Coetui Hung. Scholae Unit. Claud. obtulit pia matrona Domina vidua p. m. Johannis Szőrös junioris 1697. 3. Julii”. Biró 2000. 133. 
nevéhez füződő, Zürichben, Genfben vagy Bázelben megjelent kiadásaiból a katolikus gyưjtemény három, a református kollégiumi téka négy, az unitárius pedig öt példányt őriz.

A bibliai kommentárok tekintetében Lefebvre d’Étaples Jakab, Péter és János apostol leveleihez füzött kommentárja (Commentarii in epistolas catholicas Jacobi I, Petri II, Joannis III... Bázel 1527) egy kölni kiadású Pál-kommentárral egybekötve került a jezsuita kollégium tulajdonába, valószínűleg az 1603-as pusztítás után juttatta vissza a könyvtárnak Ölyvesi Gergely. ${ }^{20}$ Jóval gazdagabb a református kollégium kommentáranyaga, Petrus Martyr Vermigli, Erasmus, Johannes Oecolampadius, Konrad Pellikan, Bartholomeus Westhemer, Wolfgang Musculus Bázelben, Zürichben és Genfben a 16. században megjelent múvei már a 17. század végén a könyvtárba kerültek tudós lelkipásztorok, mint Szatmárnémeti Mihály vagy Krizbai György adományaként. ${ }^{21}$ Erasmus Annotationes in Novum testamentum (Bázel 1540) c. múve az unitárius kollégium könyvtárába került, ${ }^{22}$ János és Lukács evangéliumához írott parafrázisait (Bázel 1548) pedig két példányban ôrzik ugyanott. ${ }^{23}$

Az egyházatyák múveinek megjelentetését elsősorban bázeli könyvkiadók vállalták fel, közülük kétségkívül Frobenius kiadványai a leghíresebbek. ${ }^{24} \mathrm{E}$ kötetek természetesen a katolikus Lyceum-könyvtárban találhatók nagyobb számban, jó részüket még 1607 előtt szerezték be a Jézus-társasági atyák. Augustinus műveinek bázeli kiadásai $(1506,1528)$ három példányban is megvoltak, mellettük Basilius Magnus, Irenaeus, Gregorius Nazianzenus, Iohannes Chrysostomus, Cyrillus Alexandrinus bázeli kiadású munkái kerültek a gyưjteménybe. ${ }^{25}$ Aranyszájú Szent János múveinek a bázeli Hervagius officinában 1539-ben megjelent ötkötetes kiadását a kolozsvári Johann Adam szász nációbeli szenátor ajándékozta a Jézus-társasági atyáknak 1604. január elsején, újévi ajándékképpen. ${ }^{26}$ Hieronymus leveleinek Erasmus által sajtó alá rendezett kiadása (Bázel 1516, Frobenius) és ugyancsak Frobenius által kiadott zsoltárkommentárjai (Bázel 1516) 1526-ban Pesti Gábor tulajdonában voltak, tehát az antikvár piacról kerültek Kolozsvárra. ${ }^{27}$ A kolozsvári református egyházközség 1625-ben vásárolta Nagybányán az Athanasius, Irenaeus és Hilarius bázeli kiadású műveit tartalmazó kolligátumot, ami aztán a kollégium tulajdonába került. ${ }^{28}$ Augustinus Liber de haeresibus címú, Lambertus Danaeus által sajtó alá rendezett művét (Genf 1595) első tulajdonosa 1607-ben

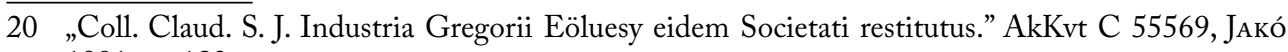
1991. nr. 183.

21 Chuonradus Pellicanus: Tomus 2 in quo continetur historia sacra, prophetae minores commentariis. Tiguri 1538. Az első táblán 16. századi magyar verssorok olvashatók, Szatmárnémeti Mihály 1676ban Kolozsváron vásárolta meg. R 83328. Petrus Martyr Vermilius: In epistolam S. Pauli...ad Romanos...commentarii. Basileae 1570 - In Pauli priorem ad Corinthios epistolam... commentarii. Tiguri 1571. „Collegii Claud[iaci] ex tes[tamen]to Cl[arissimi] D[omini] Krizbai.” R 8332583326.

22 AkKvt U 54401.

23 AkKvt U 64339, U 61816.

24 Peter G. Bietenholz: Der Basler Buchdruck und die Reformation. Scriptum, Szeged, 1998. 7.

25 Lásd Jakó 1991.

26 Uo. 99.

27 AkKvt C 90919, Jakó 1991. nr. 215, 217.

28 Athanasius: Opera. Basileae 1564. - Irenaeus: Libri adversus haereses. s.l. 1570. - Hilarius: Lucubrationes. Basileae 1570. „Comparatus Eccl(esi)ae orthodoxae Claud[iacae] per prudentem ac circumspectum d[ominum] Gregorium Szegedi Anno 1625 mense Junio Rivulini a Gregorio Gyu- 
köttette be piros pergamenbe, majd Krizbai György lelkipásztor szerezte meg. ${ }^{29}$ Theodor Beza 1570-ben adta ki Genfben Athanasius és Basilius szentháromságot tárgyaló műveit, a nyolcadrétű kötetet a lengyel-litván lelkipásztoroknak ajánlotta, hogy használhassák az unitáriusokkal folytatott vitákban. Egyik példánya a kolozsvári református könyvtárba került Kiséri György marosvásárhelyi kollégiumi tanár hagyatékából 1716 után, korábban viszont Londonban kapta ajándékba 1707-ben Spademann teológiai professzortól egyik tanítványa. ${ }^{30}$ Pszeudo-Dionüsziosz Areopagitész, a sokat vitatott 5. századi görög teológus és filozófus Theologia mystica címú, Marsilio Ficino által sajtó alá rendezett munkáját 1681-ben adományozta a református tanintézetnek Bánffi Mihály. ${ }^{31}$ A korai keresztény egyháztörténet-írók (Eusebius, Rufinus) Auctores ecclesiasticae historiae címen Wolfgang Musculus és Joachim Camerarius által sajtó alá rendezett gyüjteménye többször is megjelent a bázeli Frobeniusműhelyben, az 1535-ös és az 1539-es kiadás egy-egy példánya az unitárius kollégium könyvtárába került, az 1557-es viszont a református gyüjteménybe jutott. ${ }^{32}$

A 16. század lutheránus és református teológia irodalmának svájci kiadású múvei a református és az unitárius kollégium könyvtárában találhatók nagyobb számban. Igen gazdag például a református gyüjtemény bibliai kommentáranyaga. Konrad Pellikan zürichi kiadású Commentaria bibliorum c. múvének két kötete $(1536,1538)$ került ide Krizbai György, illetőleg Szatmárnémeti Mihály hagyatékából, mindkettő már magyar tulajdonban volt a 16. században. ${ }^{33}$ Peter Martyr Vermigli két ószövetségi kommentárkötetét (Zürich 1571, 1575) Jenei G. István kolozsvári lelkipásztor egy korábbi magyar tulajdonostól szerezte, az olasz származású svájci szerző Pál leveleihez írott magyarázatainak kolligátuma (Bázel 1570, Zürich 1571) pedig Krizbai György hagyatékából került a református főiskola könyvtárába. ${ }^{34}$ Martin Bucer, az Angliában elhunyt német református teológus bibliamagyarázatai (Bázel 1536, 1562) három példányban vannak meg az unitárius könyvtárban, ${ }^{35}$ Scripta anglicana c. ívrétű gyüjteményes kötete viszont a református bibliotékába került a 17. század végén, legko-

lai ejusdem Rivulinae cive prudenti” „Collegii Orthod[oxi] Claudiaci” AkKvt 82440-82442, Sipos 1991. 25.

29 Super ex libris: „G: F: W. 1607.” „Est Coll(egii) Claud(iaci) ex legatione clar(issimi) Krizbai”. AkKvt 82557, Sipos 1991. 32.

30 „London 1707 March. ex oblatione celeber. viri d. Spademanni ss. t. doct. et philologiae professoris acutissimi dolassimi Londini fautoris benignissimi.” „Georgii Kiséri 1716”, AkKvt R 127182.

31 Dionysius Areopagita: De Mystica theologia ad Timotheum liber. [Basileae 1561] címlap hiányzik; Adamus Henricpetri: Sententiae pulcherrimae ex Marsilii Ficini...operibus... Basileae 1561. „Ex donatione G[ene]rosi adolescentis Michaelis Bánfi possidet Orthod[oxum] Collegium Claudiopolitan[um] ab a[nn]o 1681.” R 83781-83782.

32 1535: U 74435, 1539: U 55517, 1557: R 82977.

33 Chuonradus Pellicanus: Commentaria bibliorum. Tomus primus. Tiguri 1536. „Sum Casparis V. Thurj.” „Est Stephani P. Thornai.” „Coll[egii] Claud[iaci] ex legatione clar[issimi] Krizbai”. Chuonradus Pellicanus: Tomus 2 in quo continetur historia sacra, prophetae minores commentariis. Tiguri 1538. Az első táblán 16. századi magyar verssorok, 1676-ban Kolozsváron vette Szatmárnémeti Mihály. AkKvt R 83328.

34 AkKvt R 63331-63333, AkKvt R 83325-83326, Sipos 1991.34, 63.

35 Martinus Bucerus: In sacra quatuor evangelia enarrationes. Basileae 1536. AkKvt U 63363, U 75760, Martinus Bucerus: Praelectiones in epist. Pauli ad Efesios. Basileae 1562. AkKvt U 74745. 
rábbi tulajdonosa, Szenczi Molnár Albert 1613-ban vásárolta Majnafrankfurtban. ${ }^{36}$ Heinrich Bullinger Máté evangéliumához írott kommentárjának ívrétű zürichi kiadását (1542) az unitárius kollégium hallgatói forgatták. ${ }^{37}$ Általában elmondható, hogy Bullinger svájci kiadású teológiai traktátusaiból és föleg kommentárjaiból a református és az unitárius könyvtárban ma 24 példányt őriznek.

Bullingerhez hasonlóan Johann Oekolampadius, Zwingli utóda is kommentárköteteivel van jelen a kolozsvári református könyvtárban, egyik genfi kiadású (1558) kommentárját lengyel tulajdonos vásárolta meg 1565-ben, egy századdal később magyar kézben volt, majd egy erdélyi lelkipásztor adományozta a kolozsvári kollégiumnak. ${ }^{38}$

Martin Luthernek csupán néhány korai műve jelent meg Svájcban, közülük egy sem került a kolozsvári könyvtárakba. Wittenbergi tanártársa, Philipp Melanchthon munkái közül a közkedvelt retorikát adták ki Bázelben Martin Crusius tübingeni klasszika-filológus közremúködésével, egy példányát Krizbai Györgytől örökölte meg a református kollégium. ${ }^{39}$

Jean Calvin, azaz Kálvin műveinek erdélyi elterjedését Ôsz Sándor Előd vizsgálta, megállapításai szerint a református és unitárius lelkészek a 16-17. században a genfi reformátor teológiai munkáit, kommentárjait és vitairatait egyaránt igyekeztek megszerezni. ${ }^{40}$ Jól megfigyelhető ez a kolozsvári protestáns főiskolák könyvtárainak gyarapodásában, a református iskola tékájába például még 1656 előtt bekerült a Harmonia ex tribus Euangelistis (Genf 1563) az Apostolok cselekedeteihez írott kommentárjával (Genf 1564) egybekötve. ${ }^{41}$ Ugyancsak korai beszerzés a Joachim Westphal evangélikus teológussal folytatott úrvacsoravita gyújtőkötete. ${ }^{42}$ Kálvin fő múve, az Institutio christianae religionis ma egyetlen példányban van meg a könyvtárban, az 1569-es genfi kiadás több magyar tulajdonos után Viski Cseh Mártonhoz, a kollégium szeniorjához került 1728-ban, aki végrendeletileg hagyományozta egykori iskolájának. A kolozsvári unitárius eklézsia viszont már a 17. században megörökölt egy 1554-es Institutio-kiadást id. Valentin Baumgart helybéli unitárius lelkipásztortól. A Harmonia ex tribus Euangelistis 1555-ös genfi kiadása szintén 17. századi kolozsvári unitárius lelkipászto-

36 Martinus Bucerus: Scripta anglicana. Basileae 1577. Szencitől a fia, Molnár János örökölte, majd Tolnai F. Istvánhoz került, 1690-ben Szatmárnémeti Sámuel szerezte meg, a kollégium tulajdonosbejegyzése: „Coll. Refor. Claudiop.” a 17. század végére utal. AkKvt R 83322. Ôsz Sándor Előd: Hol tanult és mikor halt meg Szenci Molnár János? Magyar Könyvszemle 128(2012). 2. sz. 269.

37 AkKvt U 60772.

38 Joannes Oecolampadius: Commentarii in libros prophetarum. Genevae 1558. Tulajdonosok: Albert Koscinski 1565, Stephanus Pauli, Márkosfalvi Miklós 1673, Zalányi György széki lelkipásztor 1692, Református Kollégium 1722. AkKvt R 53346

39 Philippus Melanchthon: Elementorum rhetorices libri duo, Martini Crusii quaestionibus et scholiis explicati. Basileae 1570. AkKvt R 80474. Sipos 1991.34.

40 Ôsz Sándor Előd: Bibliotheca Calviniana Transylvanica. Kora újkori Kálvin-kiadások Erdélyben. EME-Erdélyi Református Egyházkerület, Kolozsvár, 2014. A katalógust még kéziratban használhattam a szerző szívességéből. A három kolozsvári kollégiumban található Kálvin-kötetekre vonatkozó alábbi adatok is innen származnak.

41 A kolligátumot V.Z. betújelű első tulajdonosa 1587-ben köttette be, a címlapon a tanintézet korai megnevezése olvasható: „Collegy Orthodoxj Claudiaci”.

42 Ultima admonitio ad Joachimum Westphalum. Genf 1557, Joachimus Westrhalus: Apologia Confessionis de Coena Domini contra corruptelas et calumnias Ioannis Caluini, Oberursel 1558. A kötetben a tulajdonosbejegyzés korai formája szerepel: „Scholae Orthod[oxae] Claudiopolit[anae].” 
rok és polgárok (Adam Frank, Jövedécsi András, Régeni Asztalos János) kezén forgott, majd a 18. század elején a kollégium tékájába került. ${ }^{43}$

A Jézus-társasági atyák is igyekeztek beszerezni Kálvin mûveit, a Genfben 1561-ben kiadott Institutio (Beza hitvallásával - Genf 1560 - egybekötve) a 16. században magyar tulajdonosé volt, 1701-ben került a kolozsvári jezsuita kollégium gyüjteményébe. ${ }^{44}$ Szathmári Pap Mihály kolozsvári református kollégiumi professzor könyvtárának jelentős részét 1812 után vásárolta meg az immár kegyesrendi Lyceum, ezzel több svájci kiadású Kálvin-kommentár is bekerült a könyvtárba.

Theodor Bezanak a Jakob Andreaéval Montbéliard-ban folytatott vitáját tárgyaló kiadványát (Ad acta colloqui Montisbelgardensis...responsio. Genf 1588) a református kollégium és a jezsuita könyvtár egyaránt beszerezte, ${ }^{45}$ hitvallása (Confessio christianae fidei, Genf 1583) viszont az erdélyi református történetíró, Cserei Mihály tulajdonából került az unitárius gyüjteménybe. ${ }^{46}$ Beza teológiai munkái (Epistolae theol. Genf 1573, Theses teol. Genf 1586, Praelectiones in Corinth. epist. Genf 1573) a református és az unitárius könyvtárba több példányba is bekerültek. ${ }^{47}$ Szintén e két gyưjtemény adományozói szerezték be Beza házasságjogi munkáit (Tractatio de polygamia, Tractatio de repudiis et divortiis, Genf 1587), a református kollégiumba került egyik példányt egy magyar teológiai hallgató vásárolta Wittenbergben 1598-ban és Simándi C. Boldizsárnak ajándékozta, majd Kovásznai Péter kolozsvári lelkipásztor, erdélyi református superintendens könyvespolcán kapott helyet. ${ }^{48} \mathrm{~A}$ Valentino Gentile antitrinitárius tanaival vitatkozó Beza-mü (Val. Gentilis ... haeretici impietatum ... brevis explicatio, Genf 1567) viszont csak az unitárius kollégium könyvtárában van meg. ${ }^{49}$

Igen gazdag a református prédikációirodalom svájci nyomtatványainak együttese a két protestáns kollégiumi gyújteményben. Heinrich Bullinger zürichi elsőpap Dániel próféta könyve alapján írott homíliáinak kétkötetes ívrétű kiadását (Zürich 1576, Froschoverus) mind a reformátusok, mind az unitáriusok beszerezték, mégpedig két-két példányban. ${ }^{50}$ Ugyanennek korábbi kiadása (Zürich 1565), Pietro Colonna Galatino olasz teológus és orientalista fő művével (Opus de arcanis catholicae veritatis) egybekötve már 1566-ban magyar kézen forgott, a 18. század elején került a református főiskola tulajdonába. ${ }^{51}$ Bullinger Jeremiás próféta könyvéhez írott prédikációinak 1559-es zürichi kiadása az unitárius kollégium gyüjteményét

43 Tulajdonosbejegyzése: „Sum Scholae Unit. Claudiopolitanae.”

44 Possessorbejegyzése: „Residen. Claudio. Soc. Jesu 1701.”

45 AkKvt R 83806, C 83832.

46 AkKvt U 61922.

47 AkKvt U 64529.

48 Beza más munkájával (Quaestionum et responsionum christianarum libellus. [Genf] 1584) egybekötve. „Balthasar C. Simandi 1598”, „Est Petri Kovasznai 1654”, „Coll[egii] Refor[mati] Claud[iopolitani]” AkKvt R 83154-83155.

49 AkKvt U 54758.

50 Heinrychus Bullingerus: Daniel...propheta...expositus LXVI homiliis. Tiguri 1576. AkKvt R 82447, R 85034, U 74748, U 62540.

51 Bullinger munkája után kötve Petrus Galatinus: Opus de arcanis catholicae veritatis ... ad haec Joannis Reuchlini de arte cabalistica libri tres. Basel 1561. A préselt bőrkötésen supralibros olvasható: GFG 1566, az első táblán „Sum Georgii Göncj” kihúzott bejegyzés, a címlapon „Est Mich[aelis] Sz[atmár]Némethi 16691 Febr. Göncini valet fl. 1”, „Michael Bányai” (17. sz.), „Coll. Refr. Claudiacj”. AkKvt R 83344. 
gazdagította. ${ }^{52}$ Rudolph Gualther, Bullinger lelkészutóda a zürichi egyházban, szintén több prédikációskönyvet jelentetett meg, ezeket nemcsak a protestáns kollégiumok adományozói forgatták, hanem a Jézus társasági atyák is beszerezték. ${ }^{53}$

$\mathrm{Az}$ antitrinitárius teológiai irodalom az unitárius kollégiumi könyvtárban van jelen nagyobb számban. Giacopo Aconcio Satanae stratagemata c. múve 1565-ös bázeli kiadásának két példányát oorzik itt, az egyiknek lengyel tulajdonosa volt 1647-ben, később a kolozsvári unitárius egyházközséghez került. ${ }^{54}$ Christian Francken, a Kolozsvárott is tanító antitrinitárius gondolkodó jezsuitaellenes műveinek kolligátumát (Colloquium iesuiticum. Bázel 1581) kolozsvári unitárius lelkészek (Valentin Radecius, Andreas Lachovius, Szentábrahámi Mihály) olvasták a 17. században, majd 1816 után került a katolikus könyvtárba. ${ }^{55}$ Bernardino Ochino olasz kapucinus szerzetes latinra fordított prédikációinak kolligátuma (Bázel 1561) szintén kolozsvári unitárius lelkészi könyvtárból került 1831 előtt a katolikus gyújteménybe. ${ }^{56}$

Az ókori filozófusok művei sorra jelentek meg a bázeli könyvkiadóknál, és hamar elkerültek magyar földre. Arisztotelész Nikomakhoszi etikájának Theodor Zwinger által sajtó alá rendezett kiadását (Bázel 1582) 1595-ben köttette be a tulajdonosa, a supralibros (AL SO 1595) valószínúleg Sombory Sándorra, a Heidelbergben, Páduában és talán Strassburgban is tanult erdélyi unitárius fóúrra utal. Az ívrétủ kötet aztán Szamosközi Pr. Kelemenhez került, a Jézus társasági atyák pedig 1707-ben leltározták..$^{57}$ Még két 16. századi Arisztotelész-kiadás került a jezsuita kollégium könyvtárába, ${ }^{58}$ az unitárius gyújtemény viszont egy, az arisztotelészi tanokat kivonatosan összefoglaló 1536-os kiadványt őriz. ${ }^{59}$ Ugyanott található Platón müveinek háromkötetes, a genfi Etienne-múhelyben megjelent kiadása. ${ }^{60}$

Az antik irodalom svájci kiadásai közül elsősorban a nagy összkiadásokat említhetjük. Homérosz összes múveinek kétnyelvú kiadása (Bázel 1583) 1653-ban került a református

52 AkKvt U 64580.

53 Gualther prédikációiból nyolc kötet található az unitárius (pl. Rudolphus Gualtherus: Homiliae. Tiguri 1557. AkKvt U 75811, U 52391, U 72982) és a katolikus könyvtárban (pl. C 55287), és két kötet a református gyüjteményben

54 „Sum Johannis Moszowsky 1647”, „Ecclae Unitar. Claud.”, AkKvt U 61924.

55 „Valentini Radecii Gedanen. 1607” „Ex libris Andreae Lachovii” „Michaelis Sz. Abrami”. AkKvt C 84989.

56 Bernardinus Ochinus: Liber de corporis Christi praesentia in coenae sacramento, Basileae sa. [1561?], Labyrinthi hoc est de libero aut servo arbitrio, de divina praenotione destinatione... Basileae sa. „Andreae Lachovii”, „Andreae Jövedecsi”, „Bibl. Lycei Regii 1831”. AkKvt C 55114.

57 Aristoteles: Ethicorum Nicomachiorum libri decem. Basileae 1582. „Ex libris Valentini Sa...... binales 1603. fl. 1 d. 40”, „Clementis Salini et amicorum ejus”, „Clemens Pr. Salinus Deus providebit”, „Clemens Pr. Szamosközi Maksae 16..”, „Inscriptus catalogo Residentiae Societatis Jesu Claudiopoli 1707”. AkKvt C 51583. Tonk Sándor: Erdélyiek egyetemjárása a korai újkorban 1521-1700. József Attila Tudományegyetem, Szeged, 1992 (Fontes Rerum Scholasticarum 4). 5.

58 Aristoteles címlap nélküli kötete, Basileae 1566. AkKvt C 77701, Aristoteles: De moribus ad Nicomachum libri decem. Basileae 1566. Supralibros: A M C. 1580. „Societatis Jesu Claudiop 1765”. AkKvt C 50029.

59 Aristoteles: Libelli duo. Basileae 1536. AkKvt U 64779.

60 Platon: Opera. Genevae 1578. AkKvt U 74146. Elena Damian: Ediţii stephaniene în colecţiile Bibliotecii Academiei clujene. Biblioteca şi Cercetarea XIV. 1990. 85-88. 
kollégiumba, ${ }^{61}$ a Püthagorasznak tulajdonított, Carmina aurea címen ismert szöveggyüjtemény Bázelben megjelent kötetét viszont Enyedi János kolozsvári hadnagytól kapta ajándékba a főiskola. ${ }^{62}$ Cicero válogatott müveinek és szónoklatainak 16. századi bázeli kiadásait az unitárius kollégium adományozói forgatták, a nyolcadrétű Orationes omnes (Bázel 1583) viszont a kolozsvári jezsuita kollégium egyik diákja tulajdonában volt 1600-ban, ő adományozta a főiskola könyvtárának 1604 előtt. ${ }^{63}$ Plautus vígjátékainak Johannes Sambucus által sajtó alá rendezett kiadása (Comoediae. Bázel 1568) erdélyi szász tulajdonosoktól került a református kollégium könyvtárába a 18. század elején, Terentius vígjátékait (Comoediae. Bázel 1543) viszont Tordai Ádám szerezte meg 1566 körül, majd az unitárius gyüjteménybe került. ${ }^{64} \mathrm{Eu}-$ ripidész tragédiáinak két bázeli kiadása is gazdagította a jezsuita kollégium könyvtárát a 16. század végén. ${ }^{65}$ Vergilius összes mûveinek ívrétû, bázeli nyomtatású kötete (1561) Johannes Agricola könyvtárából került ismeretlen úton-módon a kolozsvári jezsuita atyákhoz. ${ }^{66}$ Démoszthenész politikai beszédeinek görög-latin kiadását 1563-ban köttette be első tulajdonosa, 1572-ben kapta ajándékba Gyarmathi Gáspár, majd a jezsuiták katalogizálták 1604ben. ${ }^{67}$ Jellemző a jezsuiták könyvtár-gyarapítási politikájára, hogy Cicero múveinek különféle kiadásai mellé 1596-ban megvásárolták a szeminárium számára a Thesaurus Ciceronianus című szótár friss kiadását (Bázel 1583). ${ }^{68}$

A kortárs humanisták közül természetesen Erasmust kedvelték a legjobban az erdélyi könyvgyüjtők, elsősorban mondásgyüjteményeit (Apophtegmata libri, Chiliades Adagiorum stb.) és bibliai kommentárjait szerezték be nagyobb számban, de pedagógiai jellegú írásai ( $D e$ duplici verborum copia, De conscribendis epistolis) is megtalálhatók a magángyújteményekböl gyarapodó kolozsvári főiskolai könyvtárakban. Az Adagiorum Frobenius műhelyében nyomtatott példányát a kiemelkedő humanista műveltségű erdélyi püspöki vikárius és kolozsvári pébános, Adrian Wolphard köttette be 1535 -ben, ${ }^{69}$ egy másik Adagia-kiadást pedig az Itáliában vele együtt tanult testvére, Hilarius szerzett be, mindkettő a jezsuita könyvtárba került. ${ }^{70}$ Mostani - a svájci kiadásokat számba vevő - vizsgálatunk is megerősíti a korábbi megfigyelést, hogy az antitrinitárius értelmiségiek előszeretettel forgatták Erasmus köteteit. ${ }^{71}$ A Bázel-

61 Homerus: Opera quae extant omnia. Basileae 1583. „Scholae Orth[odoxae] Claudiopolit[anae] 1653.” AkKvt R 80716.

62 Pythagoras: Carmina aurea. Basileae 1559. „A[nno] D[omini] 1685 die 24 octobr[is]. Ezt a könyvet közönséges haszonra adtam a kolosvári Reformatum Collégium számára, a Collegium thecajába. ... Enyedi János mpr. Castellanus liberae regiae civitatis Kolosvar.” AkKvt R 112472.

63 „Andreae Sartorii Vecken d. 50”, „Nicolaus Jamffi Anno 1600 in Scho. Cla. Socii Jesu”, „Collegii Soc. Jesu Claudiop. 1604”, AkKvt C 53555.

64 „Adami Tordai”, AkKvt U 64249.

65 Jakó 1991. nr. 177.

66 Super ex libris: „J. A. 1565”, „Liber Johannis Agricolae”. György 1994. 48.

67 Demost henes: Olynthiacae tres, Graece et Latine. Basileae 1560. Jakó 1991. nr. 142.

68 Coelius Secundus Curio, Nizolius sive Thesaurus Ciceronianus, Basileae 1583. „In usum Seminarii Claud. S. J. 1596”, AkKvt C 55172, Jakó 1991. nr. 137.

69 Erasmus Roterdamus: Adagiorum opus. Basileae 1528, Jakó 1991. 53, nr. 170. Superexlibris: A W 1535.

70 Erasmus Roterdamus: Adagiorum chiliades tres . Basileae 1513. Uo. 54, nr. 167.

71 Dankanits Ádám: XVI. századi olvasmányok. Kriterion, Bukarest, 1974. 63-64. 
ben nyomtatott Enchiridion militis christianae (1551) az unitárius könyvtárban maradt fenn, ${ }^{72}$ ahol az Adagiorum chiliades különféle bázeli kiadásaiból ma öt példány is található. Ugyanitt vehetjük kézbe Lorenzo Valla Elegantiarum ... c. kiadványát és Petrarca összes műveinek bázeli kiadását is. ${ }^{73}$ Utóbbinak negyedszázaddal később megjelent nyolcadrétű kötetét két példányban is megtalálhatjuk a református gyüjteményben. ${ }^{74}$ Ludovicus Rhodiginus Lectiones antiquae című mondásgyüjteményét szintén kedvelték a 16. században, Bázelben háromszor is megjelent, az 1566-os kiadást erdélyi református lelkipásztorok forgatták, Csepei Sidó Ferenc kolozsvári lelkész pedig az iskola könyvtárának hagyományozta. ${ }^{75}$ Ugyanitt őrzik 1665 óta Giovanni Giovano Pontano olasz humanista költő összes műveinek háromkötetes kiadásából az első darabot, amely korábban tiszántúli lelkészek kezén forgott. ${ }^{76}$

Coccius Marcus Antonius Sabellicus nápolyi humanista történetíró összes mûveinek bázeli kiadásaiból három példány is került a katolikus gyüjteménybe, az 1538-as II.János választott magyar király tulajdonában volt, az 1560-as kiadásból az egyikben Szamosközy István erdélyi történetíró nevét olvashatjuk, a másik Johann Brassaitól került a jezsuiták tulajdonába. ${ }^{77}$ Nicephorus Callistus Xanthopolus 18 könyvből álló egyháztörténete (Historia ecclesiastica. Bázel 1562) a 18. században már három példányban is megvolt a katolikus gyüjteményben, az egyik példány Zsámboki János (Sambucus) humanista tudós könyvtárából került 1701-ben a kolozsvári jezsuiták tulajdonába. ${ }^{78}$ John Foxe angol reformátor ívrétű egyháztörténete valószínűleg Szenci Kertész Ábrahám hagyatékából jutott a református kollégium gyűjteményébe. $^{79}$

A humanista tudományok elsajátításához és műveléséhez feltétlenül szükséges szótárak és különféle szintű nyelvkönyvek nagy változatosságban jelentek meg a svájci kiadóknál, és a magyar vásárlókhoz is eljutottak. Urbano Valeriani minorita szerzetes és Martin Crusius tübingeni professzor görög grammatikáit (Bázel 1548, 1562) már 1604 előtt forgatták a jezsuita kollégium tanulói, akárcsak Thomas Linacrus modern latin nyelvtanát (Bázel 1560) vagy Calepinus többnyelvű szótárát és Forster héber-latin szótárát. ${ }^{80}$ Ez utóbbinak egy pél-

$\overline{72}$ AkKvt U 63167.

73 Laurentius Valla: Elegantiarum libri sex. Basileae 1543. AkKvt U 61800. Franciscus Petrarcha: Opera omnia. Basileae 1554. AkKvt U 75462.

74 Franciscus Petrarcha: Opera omnia. Basileae 1581. Tulajdonosok: Thordai Máté 1592, Nádudvari Péter 1735, Szilágyi Mihály 1765, Pataki Sámuel dr. 1792. AkKvt R 81058. tulajdonosok Kemény Farkas gr, Teleki Imre 1815. R 82006. Emil Pintea: Autori italieni în colecţiile Bibliotecii Academiei clujene. Biblioteca şi Cercetarea XIII. 1982.170-174.

75 „Iohannes B[uzás] Kecskemeti nunc rector Scholae Enyedien[sis] nunc v[ero] concionator Alben[sis] 1615”, Ex libris Francisci Czyepei”, „Scholae Orthodoxae Claudiopolitanae” AkKvt R 81035, Sipos 1991. 19.

76 Ioannes Iovianus Pontanus: Opera omnia in tomos tres digesta. Primus tomus. Basileae 1538. AkKvt R 81093. Sipos 1991.26.

77 JAKó 1991. nr. 376., 377.

78 GYöRgy 1994. 45.

79 Johannes Foxus: Rerum in ecclesia gestarum commentarii pars prima. Basileae 1559. Martyrum historia. Pars secunda. Uo. 1563. „Collegii ex dona[ti]one Relicti D[omi]ni Szenczi.” AkKvt R 84235-84236.

80 JАKó 1991. nr. 66., 85., 92., 136., 192., 257. 
dányát a református kollégium is adományul kapta a 17. században, ${ }^{81}$ és ide került Niccolo Perotti Cornu copiae c. latin szótára és nyelvtani kommentárja (Bázel 1532), miután erdélyi unitárius olvasók használták. ${ }^{82}$ Guillaume Budé francia humanista állította össze négy tudóstársával azt a görög-latin szótárt, amelyet a bázeli Henricpetri-múhely adott ki 1572-ben, egyik példányát a jezsuita atyák vették leltárba. ${ }^{83}$

Ami a természettudományokat illeti, a kolozsvári jezsuita kollégium 1604 előtti állományában három csillagászati, három orvostudományi és három földrajzi bázeli és genfi kiadású kötet található. Kiemelendő közülük Ptolemaiosz Opera omnia (Bázel 1541) és a vele egybekötött Geographia universalis (Bázel 1540), amelyet Krasznai Polyagrius Ferenc erdélyi értelmiségi már 1548-ban megvásárolt és beköttetett. ${ }^{84}$ Polyagrius egyébként 1550-ben szerezte meg a földtudományok megalapítójának, Georgius Agricolanak a De ortu et causis subterraneorum címú, 1546-ban Frobenius mühelyében nyomtatott munkáját Kopernikusz De revolutionibus orbium coelestium c. művével egybekötve, ezt Árkosi Benedek forgatta 1647ben, majd az unitárius kollégium könyvtárába került. ${ }^{85}$ Ugyanitt őrzik Agricolának másik két bázeli kiadású földtani, illetőleg történelmi tárgyú kötetét. ${ }^{86}$ Petrus Apianus kozmográfiájának párizsi kiadását Michael Neander bázeli megjelenésű csillagászati múvével Wolphard István köttette egybe 1562-ben, a kolligátum azonban nem a jezsuita kollégiumba került, hanem Adam Gitschner kolozsvári szász református prédikátor vásárolta meg 1617-ben, majd Dálnoki Lőrinchez került, tőle pedig az unitárius gyüjteménybe. ${ }^{87}$ Euklidész mértani munkáját első tulajdonosa 1560-ban köttette be, két korábbi magyar possessor után Almási József, a református föiskola seniora szerezte meg 1699-ben, a következő évben pedig a könyvtárnak adományozta. ${ }^{88}$ Ugyanitt őrzik Krizbai György hagyatékából Galenosz múveinek egy másik orvostudományi munkával egybekötött bázeli kiadását. ${ }^{89}$

Magyar helveticákról is beszélhetünk a 16. században, főként magyar református teológusok keltették fel a svájci kiadók figyelmét, de erdélyi szász természettudós múvét is érdemesnek tartották a nyomtatásra. Természetesen a neves teológusok munkái terjedtek nagyobb számban a magyar nyelvterületen. A jezsuita kollégium Szegedi Kis István múveire koncentrált, Assertio vera de Trinitate (Genf 1573) címú múvét (Theodor Beza egyik munkájával egy-

81 Joannes Forsterus: Dictionarium hebraicum novum. Basileae 1564. Tulajdonosok: Varsoci M. János 1607, Boldogasszonyfalvi Péter kolozsi lelkész. AkKvt R 80724.

82 Tulajdonosok: Szentmártoni Bálint 1575, Rákosi Balázs 1616, Unitárius Kollégium, Csepregi T. Ferenc 1730. AkKvt R 81791.

83 AkKvt C 74787, JaKó 1991. nr. 85.

84 AkKvt C 56495, Jakó 1991. 116. Az F C 1548. supralibros Franciscus Crasnensisként vagy Crasnanusként oldható fel.

85 AkKvt U 58489-58490. Dankanits: i. m. 78., 103.

86 Georgius Agricola: De re metallica. Basileae 1530, egybekötve másik két természettudományi munkával. AkKvt U 61905. Georgius Agricola: De mensuribus Romanorum et Graecorum. Basileae 1550, Paetus hasonló tárgyú múvével egybekötve. AkKvt U 75486. Sidonia Puiv: Circulaţia cărţilor lui Georgius Agricola în Transilvania. Biblioteca şi Cercetarea XVIII. 1994. 9.

87 Јако́ 1991. nr. 19, 303.

88 Euclides: Elementorum geometricorum libri XV. Basileae 1558. Tulajdonosok: Hadadi Ferenc 1627, Benkő Bálint 1659. Sipos 1991. 39.

89 Galenus: Epitome operum in quatuor partes digesta. Basileae 1571. Johannes Fernelius: Universa medicina in XXIII libris absoluta. S1.1580. AkKvt R 80725-80726. Sipos 1991. 33. 
bekötve) még 1693 előtt beszerezte, ${ }^{90}$ a másik kettőt 1765-ben katalogizálták a katolikus főiskola könyvtárában. Mindhárom címlapjára rávezették a „Protestans”, illetőleg a „Liber haereticus" megjegyzést, hiszen e köteteket csak a tanárok használhatták. A református föiskola könyvtárába Szegedi Kis hat műve került be, de megtalálhatók itt Szikszai Hellopoeus Bálint genfi és Fegyverneki Izsák bázeli kiadású kötete. Az unitárius kollégium könyvtára a 18 század végéig az említett három teológus múvei mellett Laskói Csókás Péter Genfben és Beregszászi Péter Bázelben nyomtatott könyvével is gyarapodott. Johann Honter brassói humanista tudós és reformátor Rudimenta cosmographica c. művének svájci kiadásai a református és az unitárius kollégium könyvtárát gazdagították négy-négy példányban. ${ }^{91}$

\section{$16^{\mathrm{TH}}$ CENTURY PRINTED BOOKS FROM SWITZERLAND IN THE LIBRARIES OF THE COLLEGES FROM CLUJ}

\section{Keywords: early modern Transylvania, Cluj, printed books, Switzerland, colleges}

The paper offers a brief analysis of the reception of the $16^{\text {th }}$ century printed books from Switzerland in early modern Transylvania as it is reflected in the collections of the colleges from Cluj. It is well known that the Helvetian typographers and the editors had a significant role in editing the most important reference books of Europe, but the spreading of these editions in Transylvania hasn't been analysed so far. The study relies mainly on the presentation of three libraries (those of the Catholic, Reformed and Unitarian college), thus it can't be considered a complete analysis of the phenomenon, however it shows some of the main trends.

\section{VOLUME DIN SEC. 16. TIPĂRITE ÎN ELVET,IA, PĂSTRATE ÎN BIBLIOTECILE COLEGIILOR DIN CLUJ}

\section{Cuvinte-cheie: Transilvania premodernă, Cluj, tipărituri, Elveția, colegii}

Studiul prezintă, pe baza volumelor păstrate în bibliotecile celor trei colegii confesionale din Cluj (romano-catolică, reformată, unitariană), modul în care cărțile apărute în Elveția în sec. 16 s-au răspândit în colecțiile bibliofililor din Transilvania. Este arhicunoscut aportul adus de către tipografii și editorii din Elveția la editarea lucrărilor științifice din Europa, iar răspândirea acestor volume în Transilvania constituie dovada receptivității față de literatura teologică, istorică, geografică sau filozofică a vremii. Este evident că volumele studiate ale celor trei colegii nu îngăduie o prezentare amănunțită a receptării acestei literaturi științifice, dar anumite tendințe pot fi observate chiar și pornind de la această succintă înșiruire.

90 Stephanus Szegedinus, Assertio vera de Trinitate, Genf 1573, Theodor Beza, Athanasii dialogi de sancta Trinitate, Genf 1570, „Domus S. J. Monostoriensis.” AkKvt C RMK 379.

91 A kolozsvári Akadémiai Könyvtár Régi Magyar Könyvtár-gyüjteményének katalógusa. Összeállította Kovács Mária, Kuszálı Eszter, Sánt ha Emese, Sipos Gábor, Szőke Imola. Szerk. Sipos Gábor. Scientia, Kvár, 2004. passim. 